\title{
PEMBUKUAN AL-QUR'AN PADA MASA USMAN BIN AFFAN (644-656)
}

\author{
Ilhamni \\ UIN Imam Bonjol Padang \\ ilhamni@uinib.ac.id
}

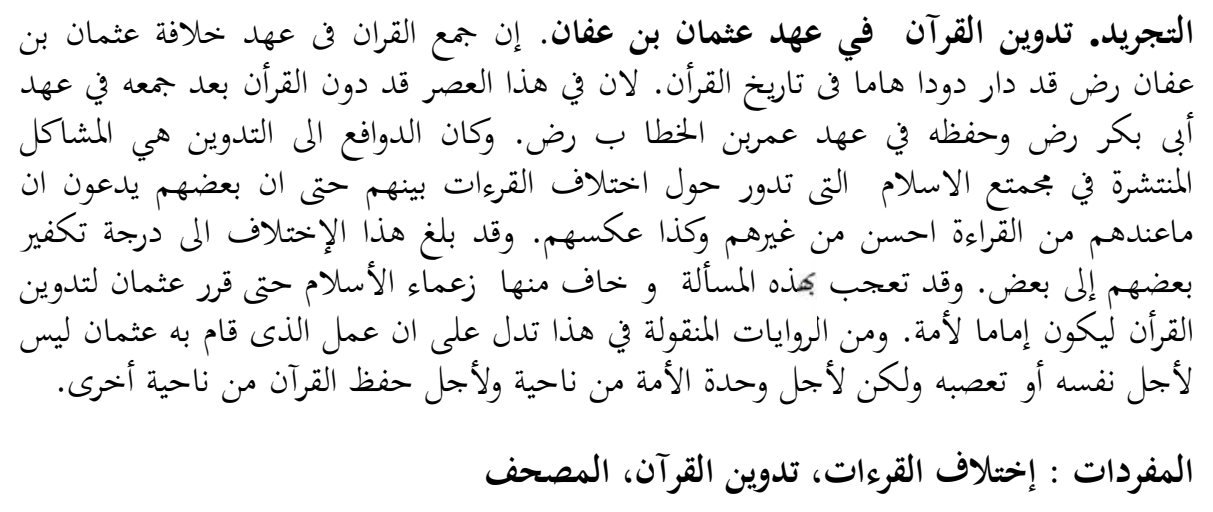

\begin{abstract}
Abstrak. Pembukuan Al-Qur'an pada Masa Usman bin Affan. Pemeliharaan AlQur'an pada masa kekhalifahan Usman bin Affan memegang peranan penting dalam sejarah Al-Qur'an. Hal ini karena pada masa Usmanlah Al-Qur'an dibukukan. Latar belakang pembukuan Al-Qur'an pada masa ini adalah meluasnya persoalan perbedaan qiraat di tengah masyarakat Islam pada waktu itu. Sebagian menganggap qiraatnya yang paling bagus sementara yang lainnya juga beranggapan demikian,bahkan perbedaan ini sudah sampai pada tingkat kafir mengkafirkan. Persoalan ini menarik perhatian dan menimbulkan kekhawatiran di kalangan pimpinan Islam, sehingga akhirnya Usman membuat keputusan untuk membukukan Al-Qur'an untuk dijadikan standar resmi bagi umat Islam. Teks - teks /riwayat yang ada mengenai pembukuan pada masa Usman ini menunjukkan bahwa Usman bekerja bukan karena kepentingan dirinya sendiri dan tidak dipengaruhi oleh unsur fanatisme dalam proses pelaksanaannya. Pembukuan yang dilakukannya adalah untuk kepentingan kesatuan umat Islam di satu sisi dan untuk pemeliharaan Al-Qur'an di sisi lain.
\end{abstract}

Kata Kunci : Perbedaan Qira' at, Pembukuan al-Qur'an, Mushaf.

\section{PENDAHULUAN}

Masa kekhalifahan Usman bin catatan sejarah Al-Qur'an dan Ulumul Affan adalah masa penting dalam Qur'an, karena pada masa inilah Al- 
Qur'an dibukukan setelah sebelumnya dikumpulkan pada masa kekhalifahan Abu Bakar Shiddiq dan mendapat pemeliharaan pada masa Umar Bin Khathab . Dipandang penting karena sebagai kelanjutan dari pemeliharaan terhadap Al-Qur'an yang sudah dirintis oleh orang-orang sebelumnya.Umat Islam setelah masa ini berpedoman kepada hasil jasa yang telah dilakukan oleh orang-orang yang diberi tanggung jawab untuk melakukan pekerjaan yang monumental ini di bawah kepe-mimpinan Usman bin Affan. Pekerjaan yang besar ini sangat pantas untuk dihargai. Kalaulah pekerjaan pembu-kuan ini tidak dilakukan pada masa Usman tentunya sejarah Al-Qur'an akan berbeda.

Keberhasilan orang-orang yang bertanggung jawab dalam hal ini bukanlah dengan cara yang mudah dan sederhana.Berbagai tanggapan dan anggapan muncul mengenai kebijakan Usman Ini.Ada yang beranggapan bahwa Usman membukukan Al-Qur'an adalah karena keinginan pribadinya atau ingin mendapatkan nama baik dan dalam proses pelaksanaannya Usman dipengaruhi oleh fanatisme. Ketika itu, ada juga sahabat yang merasa keberatan dengan ketetapan Usman bin Affan ketika ia memerintahkan kaum muslimin untuk membakar mushaf mushaf selain mushaf yang dibuat oleh tim yang ditunjuk. Keengganan ini tercatat dalam sejarah berasal dari sahabat yang diakui oleh umat Islam tentang keahliannya dalam menguasai hal-hal yang terkait dengan Al-Qur'an yaitu Ibnu Mas'ud yang dipandang sebagai salah seorang imam sekaligus guru Al-Qur'an dari kaum muslimin ketika itu yang pendapatnya juga sering dikutip dalam buku-buku tafsir yang bercorak atsar (riwayat).Di samping itu ditambah lagi dengan persoalan tekhnik penulisan yang hanya diarahkan kepada satu huruf dan juga disinyalir adanya lahn atau kesalahan i'rab/bahasa. Kesalahan ini kalau benar adanya itu artinya menunjukkan adanya kemung-kinan kesalahan dalam penulisan Al-Qur'an yang kita terima sekarang ini sebagai pedoman.

Demikianlah beberapa persoalan penting terkait pembukuan Al-Qur'an pada masa Usman bin Affan yang perlu diberikan analisa secara cermat dengan terlebih dahulu mengumpulkan data tertulis sebanyak mungkin, agar persoalan-persoalan ini bisa dianalisis secara objektif.Namun dalam kesempatan ini penulis memfokuskan kepada persoalan-persoalan yang melatarbelakangi pembukuan Al-Qur'an pada masa Usman bin Affan.

Banyak kajian seputar masalah pembukuan Al-Qur' an pada masa usman ini baik klasik maupun kekinian, namun penulis belum melihat kajian khusus mengenai motif Usman dalam membukukan Al-Qur'an

\section{INFORMASI TERKAIT PEMBU- KUAN MUSHAF}

Setidak-tidaknya ada beberapa informasi yang disampaikan dalam beberapa riwayat mengenai latar belakang pembukuan Al-Qur' an pada masa Usman bin Affan yang dicatat oleh umat Islam.Informasi ini bisa ditemukan dalam kitab hadis dan buku-buku yang memuat tentang sejarah Al-Qur'an atau bukubuku Ulumul Qur'an. 
Pada tahun $30 \mathrm{H}$ Huzaifah bin alYaman dan Sa;id bin al-Ash pulang ke Madinah dari Azerbeijan. Dalam perjalan menuju Madinah Huzaifah mengatakan, "Dalam beberapa perjalanan yang aku lakukan, aku melihat ada masalah besar yang tengah menimpa umat Islam. Bila hal ini tidak ditanggapi, maka akan terjadi perselisihan di kalangan umat Islam tentang Al-Qur'an". Sa'id bin Ash bertanya,"Apa masalahnya?Aku melihat penduduk Himsh mengklaim bahwa qira'atnya lebih bagus dari qira'at yang lain.Mereka mempelajari Qira'at dari alMiqdad.Demikian juga penduduk Damaskus juga melihat bahwa qira'at mereka lebih bagus dari yang lainnya.penduduk Kufah yang belajar qira' at dari Abu Musa dan menamai Mushaf Abu Musa dengan Lubab al-Qulub juga mengklaim qira'at mereka lebih bagus". Setelah mereka berdua sampai di Kufah , mereka menyampaikan kepada penduduk Kufah tentang kekhawatirannya.

Mayoritas para sahabat dan para tabi'in menyetujui pendapat Huzaifah tersebut, Namun kalangan pengikut qira'at Ibnu Mas'ud mempertanyakan kepada Huzaifah' qira'at mana yang kiranya anda inkari dari qira'at kami ? Mendengar jawaban dari pengikut Ibnu Mas'ud ini, Huzaifah merasa marah sambil mengatakan " Kalian adalah penduduk yang nomaden, oleh sebab itu diamlah ! Sungguh kalianlah yang salah. Demi Allah, bila aku masih hidup, maka aku akan melaporkan hal ini kepada amirul mukminin dan aku akan meminta

\section{${ }^{1}$. Abdushabur Syahin, Sejarah} Alqur'an , (Jakarta : Rehal Publika, 2008), h. 1819, cet. Ke-1 ,Judul asli Tarikh Alqur'an, penerjemah Prof. Dr. Ahmad Bachmid, Lc. kepada beliau untuk menyelesaikan masalah ini. ${ }^{2}$

Dengan rasa kekhawatirannya yang tinggi, Huzaifah ketika sampai ke Madinah melaporkan tentang apa yang diamatinya dan diperhatikannya selama perjalananya dari Azerbeijan kepada khalifah Usaman bin Affan. Ini sebagai sinyal bahwa dia sebagai salah seorang dari kalangan pimpinan umat Islam pada waktu itu memiliki tanggung jawab moral yang sangat besar terhadap AlQur'an dan juga kesatuan umat.

Salah satu inforrmasi yang menggambarkan laporan Huzaifah dan sekaligus termasuk salah satu hal yang melatarbelakangi pembukuan Al-Qur'an pada masa Usman bin Affan terlihat dalam sebuah riwayat Bukhari sebagai berikut :

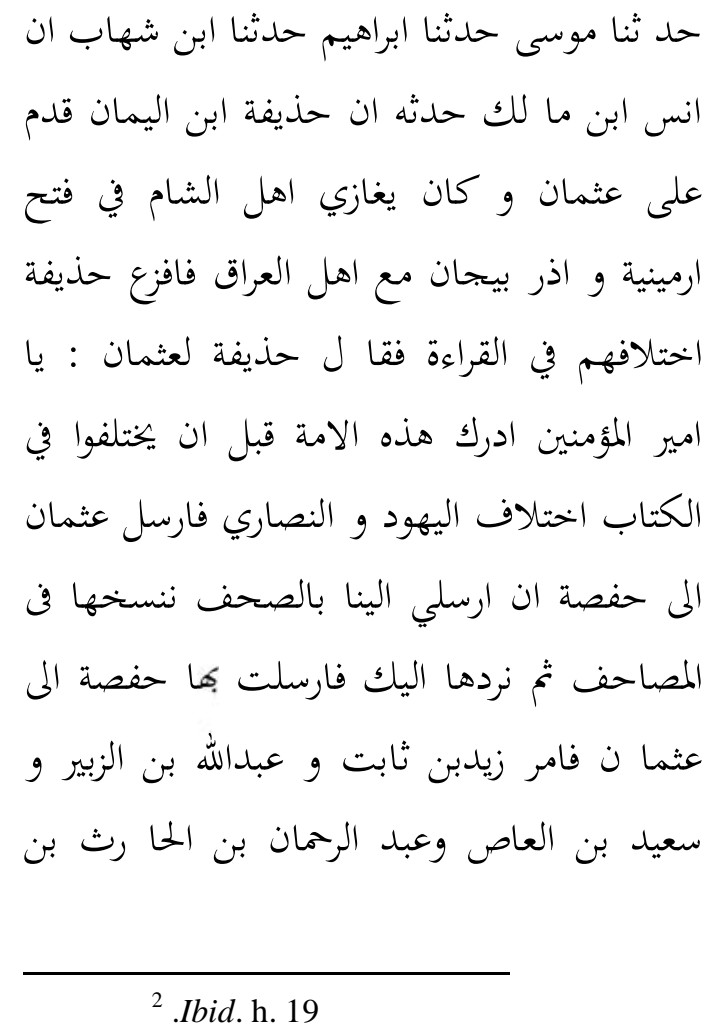


هشام فننسخوها في المصا حف و قال عثمان للرهط القرشيين الثلا ثة اذا اختلفثم انتم و زيد بن ثابت في شيى من القرءان فاكتبوه بلسا ن

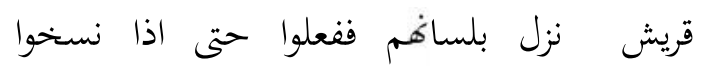
الصحف في المصاحف رد عثمان الصحف الى حفصة وارسل الم كل افق بمصحف مما نسخوا و امر بما سواه من القرءان في كل صحيفة او مصحف ان يحرق 3

“...., Huaifah ibn al-Yaman pernah datang kepada Utsman (melaporkan tentang peristiwa) dimana Penduduk Syam dengan Penduduk Irak berperang dalam penaklukan Armenia dan Azerbeijan. Ketika itu Huzaifah merasa terkejut melihat perbedaan qira'at di kalangan mereka, sehingga Huzaifah berkata kepada Usman ," Anda Satukanlah umat Islam ini sebelum mereka berselisih seperti kaum Yahudi dan Nashrani.Setelah itu Usman mengirim utusan kepada Hafsah ( dan meminta kepadanya )," Anda kirimkanlah kepada kami Suhuf (lembaran-lembaran naskah Al-Qur'an ) karena Kami akan membuat naskah menjadi beberapa mushaf. Setelah itu Kami akan kembalikan kepadamu. Hafsah mengirimkan nas-kah tersebut kepada Usman. Kemu-dian Usman menginstruksikan Zaid bin Tsabit, Abdullah bin Zubair, Sa'id bin 'Ash dan Abdurrahman bin al-harits bin Hisyam

\footnotetext{
${ }^{3}$ Ahmad Bin Hanbal Ali Ibn

Hadar al-Atsqalani, Fath al-Baari bi Syarhi al-Bukhaari, ( Kairo : Dar alHadits,2004 ) jil ke-9 h. 19-20
}

untuk menuliskannya kembali dalam beberapa mushaf. Usman berpesan kepada tiga orang di antara mereka yang berasal dari suku Quraisy," Apabila kamu berselisih pendapat tentang Al-Qur'an, maka tulislah dengan bahasa Quraisy! Karena AlQur'an diturunkan dengan bahasa mereka". Mereka menyalin suhuf ke dalam beberapa mushaf. Setelah itu Usman mengembalikan Suhuf terse-but kepada Hafsah serta mengirim-kan beberapa naskah mushaf ke beberapa daerah Islam dan dia memerintahkan pembakaran terhadap suhuf dan mushaf yang lain selain mushaf (resmi)".

Dari riwayat di atas tergambar latar belakang mendasar pembukuan AlQur'an pada periode pemerintahan Usman bin Affan.Perbedaan qira'at menjadi titik tolak pekerjaan besar yang dilakukan oleh Khalifah Usman bin Affan.Dari riwayat di atas terlihat kekhawatiran Huzaifah bin al-Yaman akan semkin meluasnya perbedaan yang bisa saja mengantarkan umat Islam kepada konflik. Hal ini tentu membahayakan persatuan umat Islam di satu sisi dan pemeliharaan Al-Qur'an di sisi lain serta pertimbangan keutuhan wilayah.

Persoalan-persoalan umat Islam pada masa Usman semakin beragam, seiring perluasan daerah melalui wilayah-

${ }^{4}$ Qira'at adalah Suatu cara membaca Alqur'an al-Karim dari seorang imam ahli qira'at yang berbeda dengan cara membaca imam lainnya, sekalipun riwayat dan jalur periwayatannya sama, baik perbedaan itu dalam pengucapan huruf ataupun bentuknya.Lihat Prof. Dr. Yunahar Ilyas dalam buku Kuliah "ulumul Qur'an, h. 155-156! 
wilayah penaklukan Islam pada enam tahun pertama peme-rintahannya mulai tahun 24 Hijrah pengangkatannya. Pengajaran Al-Qur'an pada penduduk daerah taklukan diserahkan kepada para ahli Al-Qur'an sesuai dengan kemampuan hafalan dan keahlian yang dimiliki. Namun perbedaan bacaan sedikit demi sedikit semakin bertambah walaupun bukan disengaja.Hal ini berlangsung sampai tahun ke 30 Hijrah. ${ }^{5}$

Seiring dengan perluasan wilayah Islam, para sahabat ter-sebar ke berbagai daerah. Mereka menjadi guru bagi masing-masing daerah yang mereka tempati dan membawa qira'at masing-masing yang mereka terima dari Rasulullah SAW.Umat Islam di Syam mengikuti qira'at Ubay bin Ka'ab. Wilayah Kufah mengikuti Qira'at Abdullah bin mas'ud dan wilayah lain mengikuti qira'at Abu Musa al-Asy'ari. Perbedaan tersebut menjadi masalah bagi sebagian umat Islam apalagi bagi yang tidak tahu bahwa Al-Qur'an diturunkan dalam berbagai versi qira'at. $^{6}$

Dengan meluasnya daerah Islam tentu secara otomatis meluas dan beragam pula masyarakatnya yang mereka bukan berasal dari Jazirah Arab dari berbagai suku dan bangsa. Bahkan tentunya banyak yang baru masuk Islam dan mereka tidak mengikuti proses turunnya Al-Qur'an. Di tambah lagi

${ }^{5}$ Abdussabur Syahin, Sejarah Alqur'an, ( Jakarta : PT Rehal Publika, 2008), cet ke 1 ,penerjemah Prof. Dr. Bachmid, Lc.,judul asli Tarikh Alqur'an,

${ }^{6}$ Yunahar Ilyas, Kuliah Ulumul Qur'an,( Yogjakarta ; Itqan Publishing,2013 ) Cet. Ke- 2, h. 88 mereka belajar dari guru tertentu dan tidak mengetahui informasi berbeda yang mungkin saja didapati dari guru lain yang mengajarkan Al-Qur'an di wilayah mereka masing-masing.

Kekhawatiran Huzaifah bukanlah satu-satunya yang melatarbelakangi pembukuan Al-Qur'an.

Ibnu Jarir al-Thabari dalam tafsirnya menjelaskan melalui sebuah riwayat alThabari sbb:

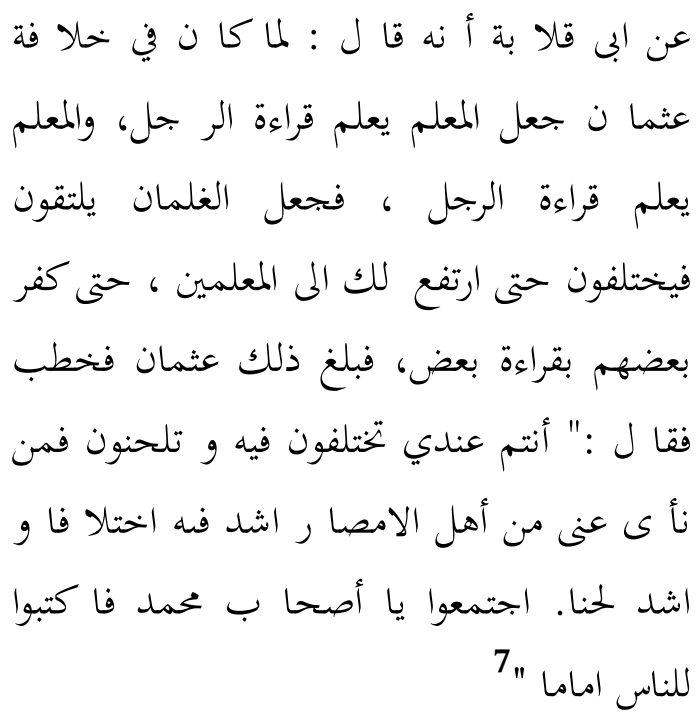

Abu Qilabah menyampaikan riwayat bahwa pada masa kekahalifahan Usman bin Affan, seorang guru mengajarkan kepada muridnya sebuah qira'at.Sehingga ketika dua orang murid yang belajar pada dua orang guru yang berbeda bertemu pada suatu waktu, mereka masing-masing mengagungkan apa yang mereka dapat dari guru masingmasing, bahkan sebagian mengkafirkan sebagian yang lain. Berita seperti ini sampai ke telinga Usman bin Affan,

${ }^{7}$ Shubhi Shalih, Mabahits Fi Ulumil Qur'an, (Beirut : Dar al-Ilmi li al-Malayin, 1988 ), cet. Ke 17, h. 80-81 
sehingga dia (memutuskan) tempat atau dalam momen peperangan, menyampaikan isi pidatonya. "Kamu mereka saling merasa heran dengan berada di tengah-tengah saya saja sudah qira'at yang lain. Tapi idealnya adalah berbeda dan salah dalam bahasa, jika diketahui bahwa semua qira'at itu bagaimana dengan orang-orang yang berasal dari Nabi, maka tentunya tidak jauh berada di kota-kota besar lainnya? ada alasan untuk meragukan satu sama tentu mereka mengalami peristiwa yang lain. Akan tetapi kenyataannya sebagian lebih dari yang kamu alami semua (yang berada di sini)."Bersatulah wahai para sahabat Muhammad!Tulislah satu imam (acuan yang bisa dijadikan pedoman secara tertulis bagi masyarakat)!.

Dari riwayat al-Thabari tersebut tergambar kondisi umat Islam yang mencemaskan yaitu per-bedaan yang tidak hanya sebagai perbedaan saja,akan tetapi sudah sampai kepada tingkat yang memba-hayakan yaitu pada tingkat kafir mengkafirkan .Seorang khalifah dalam hal ini Usman bin Affan melihat sinyalsinyal perpecahan te-ngah berproses dan tersebar di tengah-tengah masyarakat yang bera-da di bawah wilayah kepemimpinan dan tanggung jawabnya. Kekhawa-tirannya yang besar akan terjadinya konflik, perpecahan bahkan partum-pahan darah di kalangan umat Islam sendiri telah mendorongnya untuk menginstruksikan agar bekerja bersama-sama membuat sebuah mushaf yang bisa dijadikan pedoman bagi umat Islam.

Musthafa Shadiq al-Rafi'i memberikan komentar bahwa suatu kenyataan bahwa Al-Qur' an mempunyai bentuk qira'at yang berbeda-beda seiring dengan berbeda huruf yang dengannya Al-Qur'an diturunkan. Ketika penduduk suatu daerah mendenganrkan qira'at yang berbeda dengan daerah lainnya pada suatu merasa bahwa qira'atnya lebih fasih dan lebih baik dari yang lainnya dengan mengatakan bahwa "Qira'at Al-Qur' an yang kupelajari lebih baik". Sementara yang lain sebaliknya juga mengatakan justru qira'at yang kupelajarilah yang lebih baik., bahkan menginkari dan sampai pada tingkat mngkafirkan". Selan-jutnya dijelaskan oleh Abdushabur Syahin sambil menambahkan bahwa para sahabat menyaksikan perbedaan yang terjadi bukan lagi perbedaan dalam ruang lingkup dispensasi tujuh huruf, sebagaimana yang dipelajari dari Nabi. Akan tetapi sudah sampai pada tingkat kesalahan dalam periwayatan atau tata cara baca. Yang jelas ini bukan faktor kesengajaan. $^{8}$

Perbedaan ini menjadi sema-kin jelas pada waktu itu dengan keberadaan mushaf-mushaf yang lain selain mushaf yang berada di tangan Hafsah binti Umar setelah wafatnya Rasulullah SAW dalam jangka waktu yang lama sampai masa kekhalifahan Usman bin Affan. Mushaf yang paling populer pada waktu itu adalah Mushaf Ubay bin Ka'ab dan Mushaf Ibnu Mas'ud. ${ }^{9}$ Kedua tokoh ini terkenal sebagai guru yang mengajar AlQur'an pada wilayah yang berbeda

\footnotetext{
${ }^{8}$.Abdushshabur syahin,loc.cit

${ }^{9}$ Shubhi Salih, Ioc.cit
} 
sebagai-mana yang telah disebutkan di atas.

$$
\begin{aligned}
& \text { عن سويد بن غفلة قال : قال على : لا تقولوا } \\
& \text { في عثمان الا خيرا ، فوالله ما فعل الذي فعل فن } \\
& \text { المصا حف الاعن ملأ منا ، قال : ما تقولون في } \\
& \text { هذه القراءة ؟ فقد بلغنى أن بعضهم يقول : ان } \\
& \text { قراءتى خير من قراءتك ، وهذا يكاد يكون } \\
& \text { كفرا ، قلنا فيما تري ، قال أري أن يجمع النا س قراع لـ } \\
& \text { علي مصحف واحد فلا تكون فرقة ولا اختلا ف } \\
& \text { ، قلنا : فنعم ما رأيت } 10
\end{aligned}
$$

Informasi lain berkenaan dengan latar belakang ini adalah riwayat dari Suwaid bin Ghaflah : Ali bin Abi Thalib berkata " Janganlah kamu mengatakan tentang Usman bin Affan kecuali yang baik-baik. Demi Allah tidaklah kebijakan Usman tentang mushaf tersebut kecuali (atas persetujuan ) para pemimpin di kalangan kami.

Selanjutnya Usman bertanya "Apa yang kalian katakan tentang qira'at ini ? Telah sampai informasi kepadaku bahwa sebagian dari kalian mengatakan bahwa qira'atku lebih baik dari qira'atmu dan ini hampir sampai pada ( kafir mengkafirkan). Kami bertanya (pada Usman) "Apa pendapatmu tentang hal ini ?. Beliau menjawab" Menurut pendapat saya umat Islam harus berpegang pada satu mushaf sehingga tidak ada kelompok dan tidak ada

${ }^{10}$ Muhammad Abdul Azhim al-Zarqani, Manahil al-Irfan fi Ulimil Qur'an, (Beirut : Dar al-Kutub al-Ilmiyyah, 2010 ), Cet ke- 1, jil 1, h. 143 perbedaan. Kami menjawab, ? Betul pendapat yang anda kemukakan itu".

Dialog di atas menunjukkan bahwa Usman sebagai khalifah juga sudah memperhatikan fenomena tentang adanya problem sangat serius mengenai perbedaan qira'at yang tengah berkembang di tengah-tengah masyarakat. Perhatian yang sama juga diberikan oleh para sahabat lainnya. Hal ini ditunjukkan oleh dialog yang disampaikan oleh Ali bin Abi Thalib dengan penggunaan kata "kami" dan kata " mala'in" yang bisa diterjemahkan ke dalam bahasa Indonesia dengan " para pemimpin". Artinya pengamatan yang dilakukan ini dilakukan oleh para sahabat Rasulullah SAW secara umum, bukan pengamatan pribadi Usman bin Affan saja sebagai khalifah.Para sahabat sudah mengidentifikasi persoalan mendasar dan akibat yang bisa ditimbulkan dari persoalan tersebut serta solusi yang harus diambil. Ini menunjukkan secara tidak langsung sudah terjadi kesepakatan di kalangan para sahabat untuk menyatukan umat Islam dalam hal naskah mushaf yang akan dijadikan pedoman seperti juga halnya yang tertangkap oleh Huzaifah bin alYaman.

\section{KOMISI PELAKSANA KHUSUS}

Dalam beberapa riwayat disebutkan bahwa jumlah yang terlibat dalam menyalin mushaf- mushaf adalah 12 orang...Tidak tertutup kemungkinan jumlah mereka adalah 12 orang, akan tetapi kuat dugaan empat orang pertamalah yang bertugas menyalin mushaf-mushaf yang awal sementara yang lain bertugas menyalin mushaf- 
mushaf yang lain yang dikirim ke berbagai daerah.. ${ }^{11}$ Informasi ini berbeda dengan riwayat yang disampaikan oleh Imam Bukhari sebelumnya, dimana disebutkan nama-nama para sahabat yang ditunjuk oleh Khalifah Usman bin Affan sebagai tim pelaksana pekerjaan besar untuk menaskah ulang Al-Qur'an yang akan dijadikan sebagai standar Al-Qur'an yang dipedomani umat Islam.Nama-nama tersebut adalah Zaid bin Tsabit (sebagai ketua tim), Abdullah bin Zubair, Sa'ad bin al-Ash dan nama terakhir adalah Abdurrahman bin al-Harits. Yang jelas nama-nama ini ditunjuk langsung oleh Usman bin Affan.

Komisi yang terdiri dari Zaid bin Tsabit adalah berasal dari Madinah atau kalangan Anshar, sedangkan tiga orang lainnya Abdullah bin Zubair, Sa'ad bin al-Ash dan Abdurrahman bin al-Harits adalah kalangan muhajirin yang berasal dari Makkah.Mereka termasuk orangorang pilihan dan orang-orang kepercayaan.Dalam tim ini memang terlihat jumlah muhajirin ( sahabat yang berhijah dari Mekkah ke Medinah) lebih banyak dari kalangan Anshar (penduduk Madinah yang menolong masyarakat Mekkah yang berhijrah ke Medinah), sehingga Blachere salah seorang orientalis berkesimpulan bahwa lebih banyaknya jumlah kaum muhajirin ini disebabkan oleh keinginan para pemimpin pada waktu itu yang mengedepankan nepotisme dan menonjolnya rasa kesukuan yang dalam hal ini adalah muhajirin. ${ }^{12}$ Tapi kalau dilihat dari teks Bukhari tersebut bahwa alasan pemilihan

\footnotetext{
${ }^{11}$ Abdushshabbur Syahin,opcit, h. 24

${ }^{12}$. Shubhi al-Shalih, loc.cit
}

Usman bin Affan adalah karena mereka yang bertiga dipandang lebih mengetahui dengan bahasa Quraisy dan dengan bahasa Quraisylah Al-Qur'an diturunkan. Jadi alasannya adalah alasan pengetahuan terhadap bahasa Arab dan Al-Qur'an, bukan karena alasan karena pertimbangan kesukuan.Kalau seandainya ini benar tentunya tim ini tidak akan dipercayai dipimpin oleh Zaid yang berasal dari kalangan Anshar bukan dari kalangan muhajirin.

Di samping itu, tatkala Zaid ditunjuk sebagai ketua tim pelaksana pengumpulan naskah Al-Qur'an pada masa kekhalifahan Abu Bakar. Setidaktidaknya ada beberapa pertimbangan pengangkatan Zaid.

1. Zaid bin Tsabit masuk Islam semenjak usia 11 tahun yang terkenal keilmuan dan kesalehan serta banyak belajar dari Nabi Muhammad SAW.

2. Dia termasuk salah seorang penulis wahyu dan pemukanya.

3. Dia termasuk al-rasikhun fi al-ilmi atau mendalam ilmunya.

4. Dia termasuk mengerti dengan masalah fara'idh.

5. Dia termasuk paling mengerti dengan qira'at Al-Qur'an

6. Dia terkenal kecerdasannya

7. Dia termasuk masih muda ketika dipilih untuk pengumpulan AlQur'an, sehinnga mampu mengegerjakan pekerjaan besar ini.

8. Dia terkenal sebagai orang yang sangat teliti hafalan dan tulisannya berkenaan dengan Al-Qur'an.

9. Dia termasuk orang zuhud dan wara' tidak tergiur oleh tawaran bersifat duniawi dan tidak takut dengan celaan orang lain. 
138 JURNAL ULUNNUHA, Volume 6, Nomor 2, Desember 2017, hlm. 130-142

10. Dia juga pernah mempelajari bahasa orang-orang Yahudi atas perintah Rasulullah SAW. ${ }^{13}$

Jadi, dari alasan pemilihan Zaid maka dapat disimpulkan bahwa pemilihan terhadap zaid didasarkan atas alasan kompetensi pada kepriba-dian , keilmuan, dan pengalaman serta kesanggupannya serta keistimewaan-nya dari berbagai segi untuk melaksanaan pekerjan ini. Zaid bin Tsabit sebelumnya dalam pengumpulan Al-Qur'an pada masa Abu Bakar juga ditunjuk bertanggung jawab, demikian juga pada masa Nabi termasuk sebagai salah seorang kuttab al-wahyi ( penulis wahyu ) yang menjadi kepercayaaan Nabi Muhammad SAW.

\section{TEKHNIK PENULISAN NASKAH ULANG AL-QUR'AN}

Dari riwayat Bukhari sebelumnya terlihat instruksi dari Usman bin Affan tentang teknik penulisan yang harus diikuti dan dilakukan oleh tim pelaksana yaitu "yang pertama adalah jika kamu berbeda pendapat tentang AlQur'an,maka kembalikan kepada bahasa Quraisy, karena dengan Bahasa Quraisy Al-Qur'an diturunkan".Kedua Mushaf yang dijadikan landasan adalah mushaf yang sudah dikumpulkan pada masa Abu Bakar dan tetap dipelihara Umar ketika mereka masih hidup, namun setelah mereka wafat naskah ini disimpan oleh Hafsah.

Satu prinsip yang harus dipenuhi dalam menjalankan tugasa adalah bahwa

\footnotetext{
${ }^{13}$ Muhammad Bakar Isma'il, Dirasat fi Ulum Alqur'an, ( Kairo : Dar al-Manar, 1991), cet. Ke-1, h.123-124
}

ketika terjadi kasus kesulitan, maka bacaan Quraisy - suku asal Nabi- harus dijadikan sebagai pilihan. Keseluruhan Al-Qur'an meru-juk dengan cermat dan dibandingkan dengan suhuf yang berada di tangan Hafsah serta dikembalikan kepadanya ketika resensi Al-Qur'an sudah selesai dilakukan. Dengan demikian lahirlah naskah otoritatif (absah) yang belakangan disebut Mushaf Usmani. Kemudian sejumlah salinan yang dibuat dibagikan ke pusat-pusat daerah Islam. ${ }^{14}$ Pelaksanaan pekerjaan ini pada tahun 25 Hijriyah ${ }^{15}$

Perintah Usman untuk menjadikan naskah yang disimpan pada Hafsah sebagai standar penulisan walaupun mereka sendiri adalah para penghafal AlQur'an dengan alasan supaya penulisanpenulisan mushaf mesti meruju' kepada apa yang dilakukan oleh Abu Bakar dan juga telah dilakukan Umar Bin Khaththab. Abu Bakar sendiri meruju pada apa yang ditulis para sahabat atas petunjuk Nabi Muhammad SAW. Hal ini dapat menghilangkan keraguan akan AlQur'an itu sendiri. ${ }^{16}$ Standar yang dipakai dalam penaskahan ulang AlQur'an adalah suhuf yang disimpan di rumah Hafsah dan dikumpulkan secara resmi atau atas instruksi khalifahan $\mathrm{Abu}$ Bakar Shidiq dan tetap dipakai hingga masa Umar dan Usman.

Di antara riwayat yang sangat penting dalam menggambarkan tekhnik

\footnotetext{
${ }^{14}$ Rosihon Anwar, Samudera Al-Qur'an, (Bandung : Pustaka Setia, 2001), Cet ke-1 , h.79

${ }^{15}$ Jalaluddin al-Suyuthi, Al-Itqan $\mathrm{fi}$ “ulumil Qur'an, ( T.tp : Dar al-Fikri, t.th. ) Jil ke1, h. 61

${ }^{16}$ Manna' al-Qaththan, Mabahits Fi

Ulumil Qur'an, ( Riyadh : t.tp, t.th.) h. 134
} 
penulisan mushaf adalah riwayat dari al-Taisir fi al-Qira'at al-Sab'i yang Husain bin Faris dari Hani'. Dia dikutip Manna' al-Qaththan, menceritakan,"Suatu ketika saya bersama menyebutkan bahwa jumlahnya adalah Usman bin Affan pada saat mereka ( tim tujuh naskah. Naskah-naskah ini dikirim )sedang menulis mushaf-mushaf. Usman ke kota - kota besar daerah Islam yaitu mengutusku dengan membawa potongan Makkah, Syam ,Bashrah, Kufah Yaman tulang

( unta / kambing) yang lebar untuk ,Bahrain dan Madinah.. Ada lagi pendapat menemui Ubay bin Ka'ab. Pada

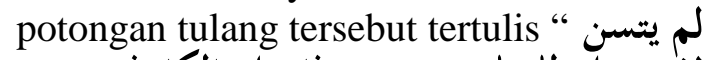

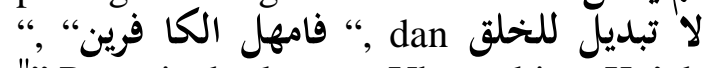
"..Perawi berkata,: Ubay bin Ka'ab meminta diambilkan tinta lalu menghapus salah satu huruf "lam" dan mengganti dengan lafaz “ "لله "، dan menulis dengan “ kemudian mengganti "فمهل “", dengan kemudian

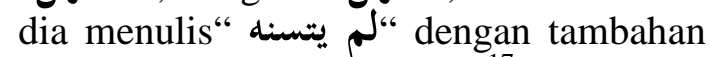
huruf " ha" di akhir. ${ }^{17}$ Hal ini menggambarkan bahwa penulisan ini juga melibatkan sahabat yang lainnya selain dari tim yang ditunjuk secara resmi oleh Usman bin Affan. Dimana Ubay bin Ka'ab termasuk seorang sahabat Nabi yang terkenal mempunyai pengetahuan yang luas terhadap Al-Qur'an.

Setelah pekerjaan penaskahan ulang diselesaikan oleh tim yang ditunjuk oleh Usman. Mushaf-mushaf yang sudah ditulis tersebut dikirim ke berbagai daerah Islam sebagai pedoman penulisan dan pengajaran oleh para shabat dan umat Islam secara keseluruhan .Mushaf-mushaf ini oto-matis menjadi mushaf resmi yang digunakan mulai masa Usman bin Affan.

Selanjutnya setelah selesai penulisan, terjadi perdebatan mengenai jumlah naskah yang ditulis oleh Tim yang empat ini. Usman bin Sa'id al-daniy salah seorang ahli Qira'at dalam bukunya

\footnotetext{
${ }^{17}$ Abdushshabbur Syahin, loc.cit
} lain jumlah keseluruhan empat naskah, daerah yang mendapatkan naskah tersebut adalah Iraq, Syam, Mesir, dan berada pada tangan Usman satu mushaf.. Sedangkan menurut al-Suyuthi adalah lima naskah .Namun, Pada akhirnya mushaf-mushaf ini menyatukan umat Islam kembali dan memutus sebab perselisihan yang menjadi problem mendasar di tengah-tengah umat Islam. ${ }^{18}$ Selanjutnya mushaf yang sudah dijadikan standar penulisan ini yaitu mushaf yang dipinjam kepada Hafsah dikembalikan lagi oleh Usman ke tangan Hafsah binti Umar dan tetap berada di tangan beliau sampai wafatnya.Pada tahun $65 \mathrm{H}$ Marwan bin al-Hakam mencoba meminta kepada Hafsah untuk dibakar tapi dia enggan memberikannya. Namun setelah beliau wafat, Marwan mengambil dan membakarnya dengan alasan, "Saya melakukan ini karena melihat apa yang ada pada shuhuf ini sudah ada pada mushaf al-Imam. Saya khawatir jika shuhuf ini tetap berada di tengah-tengah umat, maka suatu saat masyarakat akan meragukan shuhuf ini. ${ }^{19}$

\section{PEMBAKARAN MUSHAF SELAIN MUSHAF USMANI}

Teks riwayat Bukhari di atas memperlihatkan bahwa setelah selesai

\footnotetext{
${ }^{18}$ Shubhi al-Shalih, op.cit., h. 84

${ }^{19}$ Ibid., h. 83
} 
pembukuan Al-Qur'an yang dilaksanakan oleh tim khusus, maka Usman bin Affan mengambil kebijakan yang tidak populer pada waktu itu yaitu membakar Mushaf yang lain selain mushaf resmi. Kebijakan Usman bin Affan adalah sebagai kebijakan resmi sebagai kepala pemerintahan Islam pada waktu itu.Sehingga penyalinan kembali mushaf pada masa berikutnya berdasarkan kepada Mushaf Usmani yang sudah ditetapkan secara resmi.

Kebijakan Usman bin Affan ini bisa diterima dan dipandang baik oleh masyarakat pada waktu itu,kecuali pada awalnya Ibnu Mas'ud yang beliau mempunyai mushaf sendiri.Pada awalnya dia merasa enggan untuk membakar mushaf tersebut. Namun pada akhirnya dia berusaha memahami kebijakan Usman bahwa pada hakikatnya adalah demi kepentingan persatuan umat Islam dan meng-hilangkan sebab yang mengantarkan kepada perpecahan dan konflik di kalangan umat Islam sendiri. ${ }^{20}$ Sepanjang sejarah Islam peristiwa pembakaran terhadap mushaf-mushaf ini secara resmi hanya terjadi pada masa Usman bin Affan.

Walau bagaimanapun kebijakan Usman untuk membuat naskah ulang dan menjadikan mushaf yang belakangan disebut dengan Mushaf Usmani sebagai mushaf resmi serta membakar selain mushaf resmi sangat beralasan dan merupakan jasa besar bagi persatuan umat Islam dan bagi eksistensi Al-Qur'an itu sendiri, karena kondisi umat Islam pada waktu itu berada pada posisi yang mengkhawatirkan yaitu yaitu perbedaan,

\footnotetext{
${ }^{20}$ Shubhi Shalih op.cit., h. 82-83
}

perpecahan bahkan sampai pada kondisi kafir mengkafirkan. Jika hal ini dibiarkan oleh pemerintah pada waktu itu tentu kerugian besar akan menimpa umat Islam.Pekerjaan ini dilakukan bukan tanpa kritikan dari kalangan umat Islam sendiri bahkan belakangan menjadi perdebatan.

\section{KESIMPULAN}

Pembukuan Al-Qur'an pada masa Usman bin Affan dilatarbelakangi oleh persoalan- persoalan yang muncul dan tersebar di kalangan umat Islam seputar perbedaan qira'at. Perbedaan yang terjadi tidak hanya sekedar perbedaan saja, tetapi sudah sampai kepada tingkat kafir mengkafirkan satu sama lain, karena masing-masingnya mengklaim bahwa qira'at merekalah yang paling benar. Hal ini tentunya dapat mengancam persatuan umat Islam, sehingga menimbulkan keprihatinan di kalangan umat Islam itu sendiri antara lain Usman bin Affan sebagai Khalifah, Ali bin abi Thalib, Huzaifah bin al-Yaman dan Ubay bin Ka'ab.

Akhirnya mereka sepakat untuk membukukan Al-Qur'an. Usman bin Affan memutuskan untuk menyatukan umat ini dengan mushaf resmi dengan membentuk tim khusus yang bekerja membuat naskah Al-Qur'an yaitu Zaid bin Tsabit dari kalangan Anshar, Abdullah bin Zubair, Sa'id bin 'Ash dan Abdurrahman bin al-Harits bin Hisyam dari kalangan Muhaji-rin.Usman meminjam naskah shuhuf yang berada di tangan Hafshah ketika itu. Dia berpesan pada tiga orang kalangan Quraisy," Jika kalian berbeda dengan Zaid tentang sesuatu yang berkaitan dengan Al-Qur'an, 
maka tulislah dengan bahasa Quraisy, bahwa apa yang dillakukan oleh Usman karena Al-Qur'an diturunkan dengan bukan datang dari keinginan Usman bahasa mereka. Setelah mereka selesai sendiri dan dalam prosesnya tidak terlihat menulis mushaf, maka Usman mengirim unsure fanatisme ,akan tetapi atas Mushaf- Mushaf tersebut ke kota- kota kesepakatan umat Islam ketika itu dan besar Islam dan Usman memerintahkan demi kesatuan dan mencegah perpecahan untuk membakar Shuhuf atau Mushaf di satu sisi serta memelihara Al-Qur'an di selain Mushaf resmi.Penting untuk dicatat sisi lain.

\section{REFERENSI}

Al-Atsqalani, Ahmad Bin Hanbal Ali Ibn Hadar, Fath al-Baari bi Syarhi al-Bukhaari, Kairo : Dar al- Hadits,2004, jil ke-9

Anwar ,Rosihon. Samudera AlQur'an, Bandung : Pustaka Setia, 2001, Cet ke-1

Em Dasril, Sejarah Aqur'an, Padang : IAIN IB Press,2001

Ilyas ,Yunahar, Lc. MA, Kuliah Ulumul Qur'an, Yogjakarta ; Itqan Publishing,2013 cet ke-2

Ismail, Muhammad Bakar, Dirasat fi Ulum Al-Qur'an, Kairo : Dar al-Manar, 1991, cet. Ke-1,

Shalih, Shubhi, Mabahits Fi Ulumil Qur'an, (Beirut : Dar al-Ilmi li al-Malayin, 1988), cet. ke17

Al-Suyuthi, Jalaluddin, Al-Itqan $f i$ “ulumil Qur'an, t.tp : Dar alFikri, t.th. , Jil ke-1, Syahin, Abdussabur, Sejarah Al-
Qur'an, Jakarta : PT Rehal Publika, 2008 ,cet ke 1 penerjemah Prof. Dr.Bachmid, Lc.judul asli Tarikh Al-Qur'an

Syahin, Abdussabur, Saat Al-Qur'an Butuh Pembelaan Sebuah Analisis Sejarah, Jakarta : Penerbit Erlangga, 2006 , Tarikh Al-Qur'an, Kairo : Ma'had Dirasat Islamiyyat, t.th.

Al-Qaththan, Manna', Mabahits fi ulum Al-Qur'an, Riyadh : t.tp., t.th.

Al-Zarqani Muhammad Abdul Azhim, Manahil al-Irfan $f i$ Ulumil Qur'an, Beirut : Dar alKutub al-Islamiyyah,2010,

Al-Zarkasyi Badruddin Muhammad bin Abdullah, al-Burhan $f i$ Ulumil Qur'an, Beirut : DaralFikr 